Vol.

\title{
Maturity Assessment in Industry 4.0 - A Comparative Analysis of Brazilian and German Companies
}

\author{
Luciano Raizer Moura ${ }^{a^{*}}$, Holger Kohl ${ }^{b}$ \\ ${ }^{a}$ Federal University of Espirito Santo State (UFES/DTI), Av. Fernando Ferrari 514,Vitória 29075-910, Brazil \\ ${ }^{b}$ Fraunhofer Institute for Production Systems and Design Technology IPK, Pascalstraße 8-9, Berlin 10587, Germany
}

\begin{abstract}
The article presents a comparative analysis of maturity level in Industry 4.0, of Brazilian companies with German Industry, seeking to identify learning opportunities to increase competitiveness. It was used the maturity model in Industry 4.0 developed by VDMA (German Mechanical Engineering Industry Association), applied to German companies, serving as benchmark. The same model was applied to Brazilian companies, from the State of Espírito Santo, located in the most developed region of the country, but with lower industrial density, and which has great challenges to increase its participation in the national and international markets. A field research was carried out with 46 industries, which participated in workshops to understand the fundamentals and to evaluate the maturity level in Industry 4.0. The individual results were processed by the platform of VDMA, indicating the levels in six dimensions of the model and the general result on a scale of 0 to 5 . The results of all companies were tabulated, allowing the comparison with the research carried out with German companies. The study showed that, on average, Brazilian companies have the same level of maturity of German companies in readiness for Industry 4.0, with grade 0.9 in a scale of 0 to 5 . But, there are significant differences in compared dimensions. 5.6\% of German companies are at the advanced level in Industry 4.0, especially the technology developers, while Brazilian companies studied are still at the most basic levels. Both Industries are skeptical about investments in Industry 4.0 and the level of evaluation on Strategy dimension is still low. The comparison of expectations and difficulties allowed identify essential points to support these companies to follow the way to Industry 4.0 .
\end{abstract}

\section{Keywords:}

Industry 4.0;

Maturity Model;

Brazilian Industry;

Digital Transformation;

German Industry.

\section{Article History:}

$\begin{array}{llll}\text { Received: } & 16 & \text { June } & 2020 \\ \text { Accepted: } & 25 & \text { September } & 2020 \\ \text { Published: } & 01 & \text { October } & 2020\end{array}$

\section{1- Introduction}

We live a new era, the so-called Fourth Industrial Revolution. Our lives, customs, products and companies are being strongly impacted by new technologies and new business models developed from the shift to the 21 st century. The increasing use of new technologies, such as artificial intelligence, advanced robotics, internet of things, autonomous vehicles, 3D printing, nanotechnology, as examples, are designing a new world. According to Klaus Schwab, founder and CEO of the World Economic Forum, "the changes are so profound that, from the perspective of human history, there has never been a time of greater promise or potential peril". He also emphasizes that what distinguishes this new era is the speed, amplitude and depth of the transformations [1].

These changes have a strong impact on companies that need to adapt to this new technological era, also called digital transformation, which represents "the adoption of business processes and practices to help the organization compete effectively in a world increasingly digital" [2]. The global digital economy should amount to US\$23 trillion in 2025 and is expected to grow at a rate 2.5 times higher than the growth of the global economy in other sectors over

\footnotetext{
* CONTACT: Luciano.moura@ufes.br

DOI: http://dx.doi.org/10.28991/esj-2020-01237
}

(C) 2020 by the authors. Licensee ESJ, Italy. This is an open access article under the terms and conditions of the Creative Commons Attribution (CC-BY) license (https://creativecommons.org/licenses/by/4.0/). 
the next few years [3]. It's estimated that the digital economy represents about 5\% of global GDP and 3\% of global employment [4]. These numbers show the great impact that digital transformation is already promoting in the world.

The technological domain is a determining factor for the competitive position of nations and companies. Germany, the world's fourth largest economy, has defined advanced technology as a clear strategy to become a world leader in innovation, reinforcing its position as an industrial and export leader. Innovative solutions were defined like the factor to drive prosperity and sustain the quality of life of its population. With this, laid the foundations of a new era in manufacturing, Industry 4.0, with a political, strategic and technological vision to further strengthen its companies and increase its competitiveness in the world [5].

Brazil, as the ninth largest economy in the world [6], in order to remain competitive and seek the growth of its Industry, must position itself in the face of this new reality of digital transformation. And a good way for this is to focus in reference leading countries in the technological race, such as Germany, learning and creating the proper means for technological modernization of their companies.

This article aims to identify essential points for strengthening Brazilian companies facing this new era of digital transformation that is impacting the world, comparing with German Industry that seeking leadership in Industry 4.0. It presents a comparative analysis of maturity in relation to Industry 4.0, based on a model and study carried out in the German Industry by VDMA, the German Mechanical Engineering Industry Association. A field research, using the same model, was carried out with Brazilian companies, notably from the State of Espírito Santo (ES State), southeastern region of Brazil, to seek reference and learning that could guide these companies to position themselves facing this new order in the world industry.

Despite the very different realities, it's important to companies from developing countries, such as Brazil, in regions with lower industrial density, such as the Espírito Santo State, to compare themselves to benchmarks such as the German Industry, and define their strategic positioning to the world market. As quoted by Schwab, this new era emerges as threat, but also as opportunity, and can contribute to the growth of companies and nations [1]. Provided that the right measures are taken and in time to allow the competitive strengthening of these companies.

\section{2- Research Methodology}

In order to allow a comparison with the German Industry, field research was carried out with Brazilian companies, from Espírito Santo State, using the same Industry 4.0 maturity evaluation model applied to German companies, used by VDMA (German Mechanical Engineering Industry Association). This model is called Industrie 4.0 Readiness, which assesses how well prepared a company is in relation to the fundamentals of Industry 4.0. It was developed by Aachen University and sponsored by the Impuls Foundation [7].

The field research was carried out with the steps showed in Figure 1. Initially, was implemented the research planning to define the methodology and identify the business sectors to be involved. There was the support of employers' unions, which represent the interests of the industries, communicating to members and inviting companies to participate. Six workshops were held with the participation of 46 industries, located in the State of Espírito Santo, from sectors of Plastic, Food and Beverage, Metalworking, Chemical, Furniture and Clothing. Of this total, 50\% were small companies, $28 \%$ medium and $22 \%$ large.

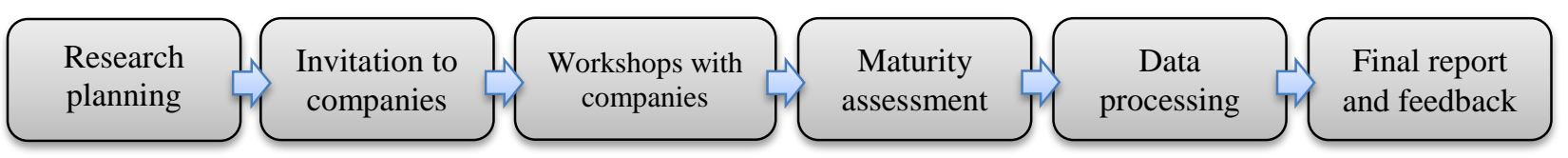

Figure 1. Steps of research methodology.

In the workshops, the concepts and fundamentals of Industry 4.0 were presented, and carried out the evaluation of Industry 4.0 maturity level, developed by VDMA, available online in https://www.industrie40-readiness.de/?lang=en [7]. Each company answered the questions of the VDMA model, individually and according to their reality, with the researcher support. The individual results were processing by the platform, indicating the levels for each of the six model dimensions and the overall result on the scale of 0 to 5 . The results presented in the reports were tabulated, getting the indexes that allowed the comparison with the results of the survey conducted by VDMA with the German companies [7]. A final report was prepared with the general results of the survey and the feed-backs for the participating companies were presented.

\section{3- Industry Challenges}

New and advanced technologies generate innovative products and services that transform the world [8]. Even in this new digital age, many products are still in the real world, and are produced by industries. And how will the 
industries be in this new era? Will produce innovative products in the conventional way? Or will the factories be heavily impacted by the Fourth Industrial Revolution?

Certainly a new era in manufacturing is emerging. The smart factory represents a leap forward from more traditional automation to a fully connected and flexible system and are a key feature of Industry 4.0 [9-10]. Smart Factories are capable of managing complexity, are less prone to disruption and are able to manufacture goods more efficiently [11]. Providing current companies the infrastructure and intelligent technologies to achieve the aimed goals of modern manufacturing represents a major challenge for the global Industry and it is obtained by adopting new models, new forms, and new methodologies to transform the traditional manufacturing system into a smart system [12].

Major industrialized nations, such as Germany, put the development of Industry 4.0 in the center of their industrial policy strategies to increase their competitiveness. And Brazil, if wants to participate as a global player in manufacturing, needs to do the same. The economic, social, political and business realities are quite different when comparing Brazil and Germany. But the intention is to create referential and learning, since the ability of Brazilian industry to compete internationally will depend on its capacity to adapt to this new world order and to promote the transformation of its Industry [13].

Germany is one of the world leaders in the development of advanced technologies, being part of its strategic vision to support research and development, aiming to build a strong Industry [14]. It's the largest economy in Europe, the $4^{\text {th }}$ GPD in the world and the $3^{\text {rd }}$ largest exporting country in the world, with more than US $\$ 1.48$ trillion in 2019 , of goods with high added value, such as automobiles, machines, chemicals and electronics [15]. Brazil ranks 26th in exports, with about US \$224 billion, notably with agricultural commodities such as soy and coffee, as well as iron ore, steel and footwear $[15,16]$.

The "Industrie 4.0" (original name of the project in the German language), has become one of the ten "projects of the future" identified by the German Government as part of its 2020 High Tech Strategic Plan, entitled "The New High-Tech Strategy - Innovations for Germany" [5]. It's understood as a great opportunity for Germany to assert its technological leadership role and to establish itself as a major supplier of technologies for this new industrial era [17].

The Brazilian Industry, to increase its competitiveness, must position itself strategically in front of this new scenario. It represents $21 \%$ of the Brazilian GDP, which was US\$2.055 trillion, and 20,2\% of the country's workforce, that is 104.2 million people. Brazilian industry accounted for only $2.1 \%$ of total manufactured goods worldwide [18]. The country ranks 71nd in the competitiveness ranking of the World Economic Forum [19] and 66th in the Global Innovation Index, as defined by Cornell University [20]. This situation, in the context of competition and innovation, is not in line with Brazil's position as the world's $9^{\text {th }}$ largest economy. If the challenge of Germany is to lead the technological race, Brazil is to expand its insertion in the production and international trade of manufactured goods, which in other points will depend on the increase of productivity and innovation [13]. The Industry 4.0 presents opportunities for developers and suppliers of solutions to a new technological environment [21].

In the Brazilian regional view, there are different situations. Espírito Santo, one of the states in the Southeast, the most developed region in the country, had a total of 9.898 industrial companies in 2020, accounting for $2.1 \%$ of industrial companies in Brazil and 1.8\% of industrial GDP, according to CNI (National Industry Confederation) [18]. The state has the $14^{\text {th }}$ largest population, the $14^{\text {th }}$ largest GDP in the country, occupies the 10th position in the industrial GDP and $8^{\text {th }}$ position in exports. The main industrial sectors are oil and gas, mining, metallurgy, pulp and construction. It holds important industrial plants of companies such as: Petrobras, being the largest producer of gas and the second of oil; Vale, being the largest iron ore pellet production complex in the world; Fibria, the world's largest producer of bleached eucalyptus pulp; and the steelmaker Arcelor Mittal. There are also other industrial sectors such as metalworking, marble and granite, clothing, furniture, food and beverages, chemical, plastic, among others, with thousands companies, been the most part small and middle companies [18].

The Espírito Santo Industry's challenge, in addition to the search for higher productivity, is to increase its participation in the national scenario and also seek greater participation in the sale of manufactured goods in the international market. This can be done using its natural performance in international trade, as it occupies the 8th position among the Brazilian states, despite having the $14^{\text {th }}$ GDP. Another factor that distinguishes the state, as potential, is to have the best result in the national high school evaluation [22]. Innovation and modernization of the production infrastructure, added to the competitive potential of the state, can be a decisive factor in overcoming the challenge of increasing their participation in national and international scenarios. For this, nothing better than compare companies from ES State to the Industry that wants to lead the technological race in the world, that is the German Industry. 


\section{4- Industry 4.0 - A New Era in Global Industry}

The initiative to envisage a new era in manufacturing, considering the intense digital transformation of the world, was from Germany. In 2011, at the Hannover Fair, the proposal of Industrie 4.0 was presented, which became an important action of the German Government to boost its Industry [21]. Many German organizations, companies, government and academia have started to build the foundations of Industry 4.0, developing technologies, concepts, models and methods. Since then, there has been a strong evolution of what this new Industry really represents.

Industry 4.0, in practice, consists of a smart factory, able to managing complexity and manufacturing products more efficiently [11]. Introduced the concept of "Cyber Systems" and aims to connect embedded systems and intelligent production facilities to generate a digital convergence between industry, business and internal functions and processes [23]. Smart factories are endowed with enabling technologies for Industry 4.0. In the view of BCG (Boston Consulting Group), Industry 4.0 refers to the convergence and application of nine digital industrial technologies: Advanced Robotics, Additive Manufacturing, Augmented Reality, Simulation, Horizontal and Vertical Integration, Internet of Things (IoT), Cloud Computing, Cyber Security and Big Data and Analytics [24]. Depending on the type of company, some technologies apply more than others, and therefore, some companies invest predominantly in some of these technologies, being defined as essential, such as IoT, Big Data and Analytics and Cloud Computing [25].

The adoption of this new industry must generate many impacts, in economic, technological and also social fields. Some studies indicate that the impacts of Industry 4.0 will be positive in the economy, in particular by generating higher revenues for companies and increasing countries' GDP. For example, Germany's Mechanical and Manufacturing Industry is expected to grow by $2.1 \%$ by 2025 and increase revenues by $€ 23$ billion, according to a study by Bitkom and Fraunhofer/IAO [26]. Another study, from BCG, indicates that connectivity and interaction between products, machines and human beings will make production systems $30 \%$ faster and $25 \%$ more efficient and will raise mass customization to new levels [24]. McKinsey cites that the promise of Industry 4.0 is to increase business efficiency by 30 to $50 \%$, and reduce resource consumption by 20 to $25 \%$, providing significantly higher revenues of up to $30 \%$ [27].

Regarding the impacts on job creation, it is estimated that, in the short term, the trend towards greater automation will reduce the number of low-skilled workers who perform simple and repetitive tasks. The adoption of advanced technologies in German manufacturing, due to the growth it stimulates, will lead to a $6 \%$ increase in employment over the next ten years, generating 390.000 jobs [24].

In order to obtain as many benefits as expected, high investments in the restructuring of the Industry will be required. It is estimated that, to adapt production processes and incorporate Industry 4.0, require to German producers invest about $€ 250$ billion over the next ten years [24]. A global PwC study on Industry 4.0, cited such as the world's largest research with more than 2,000 companies in 26 countries, indicates that over the next five years, global industrial product companies will invest $\$ 907$ billion a year, representing about 5\% of annual revenues [28].

Despite all this potential, most companies have serious problems to grasp the overall idea of Industry 4.0, and can't relate it to their particular business strategy and also in determining the level of development in relation to the vision of Industry 4.0. The difficulty is to define, clearly, actions and projects, and so, new methods and tools are needed to provide guidance and support to align business strategies and operations. In this sense, many organizations have proposed reference models that allow a company to identify how well is prepared or adequate in relation to Industry $4.0[29]$.

\section{5- Maturity Model Used in the Research}

Many models were elaborated to present the concept of Industry 4.0 and to evaluate the company's adequacy level to this concept. Considering that the purpose of this study was to conduct a comparative analysis of the Brazilian business reality with the German one, which had the initiative and aims to lead this theme, it was fundamentally important to use a model that presented evaluation results applied to business reality or closer to that reality.

Some models were identified and analyzed which could contribute to the research objectives. Among the models that proposed to evaluate the level of maturity in Industry 4.0, four models were selected that presented more relation with the objectives of the study, those developed by:

- Acatech - Industrie 4.0 Maturity Index [11];

- PwC - Global Industry 4.0 Survey [28];

- Fraunhofer Austria Research / Vienna University of Technology [29];

- VDMA and IMPULS Stiftung - Industrie 4.0 Readiness [7]. 
The model chosen to be used in field research was developed by VDMA/Impuls, called Industrie 4.0 Readiness [7]. This model was chosen based on criteria and the reasons were: a) Consider the business reality; b) Ease of use; c) Online evaluation platform; d) Allows comparison with other companies in the sector; And finally, e) There is a research with results released of German Industry.

The Industrie 4.0 Readiness model allows the evaluation of maturity in Industry 4.0 and is based on six dimensions and criteria organized in eighteen items, which are presented in the Table 1:

Table 1. Dimensions and criteria of the maturity model evaluation in Industry 4.0 of the VDMA [7].

\begin{tabular}{|c|c|}
\hline Dimensions & Criteria \\
\hline $\begin{array}{l}\text { Strategy and } \\
\text { organization }\end{array}$ & $\begin{array}{l}\text { - } \text { Implementation Status of the Industry Strategy } 4.0 \\
\text { - Operationalization and strategy review using a system of indicators } \\
\text { - Industry Related Investments } 4.0 \\
\text { - Use of technology and innovation management }\end{array}$ \\
\hline Smart factory & $\begin{array}{l}\text { - } \quad \text { Digital modeling } \\
\text { - Equipment Infrastructure } \\
\text { - Use of data } \\
\text { - IT systems }\end{array}$ \\
\hline Smart operations & $\begin{array}{l}\text { - } \text { Sharing Information } \\
\text { - Cloud usage } \\
\text { - IT Security } \\
\text { - } \quad \text { Autonomous processes }\end{array}$ \\
\hline Smart products & $\begin{array}{l}\text { The readiness for smart products is determined by looking at the additional ICT } \\
\text { functionality in the products and the extent to which usage phase data are analyzed. }\end{array}$ \\
\hline Data-driven services & $\begin{array}{l}\text { - } \text { Availability of data-driven services } \\
\text { - Share of revenues derived from data-driven services } \\
\text { - Sharing of used data }\end{array}$ \\
\hline Employees & $\begin{array}{l}\text { The readiness in the employees dimension is determined by analyzing the skills of } \\
\text { employees in various areas and by the company's efforts to acquire new skills. }\end{array}$ \\
\hline
\end{tabular}

The model indicates the readiness company in six levels, in a scale of 0 to 5, being: Level 0 - Outsider; Level 1 Beginner; Level 2 - Intermediate; Level 3 - Experienced; Level 4 - Expert; Level 5 - Top performer. These six levels are grouped into three groups: Newcomers (0 and 1), Learners (2) and Leaders (3, 4 and 5), as shown in the Figure 2.

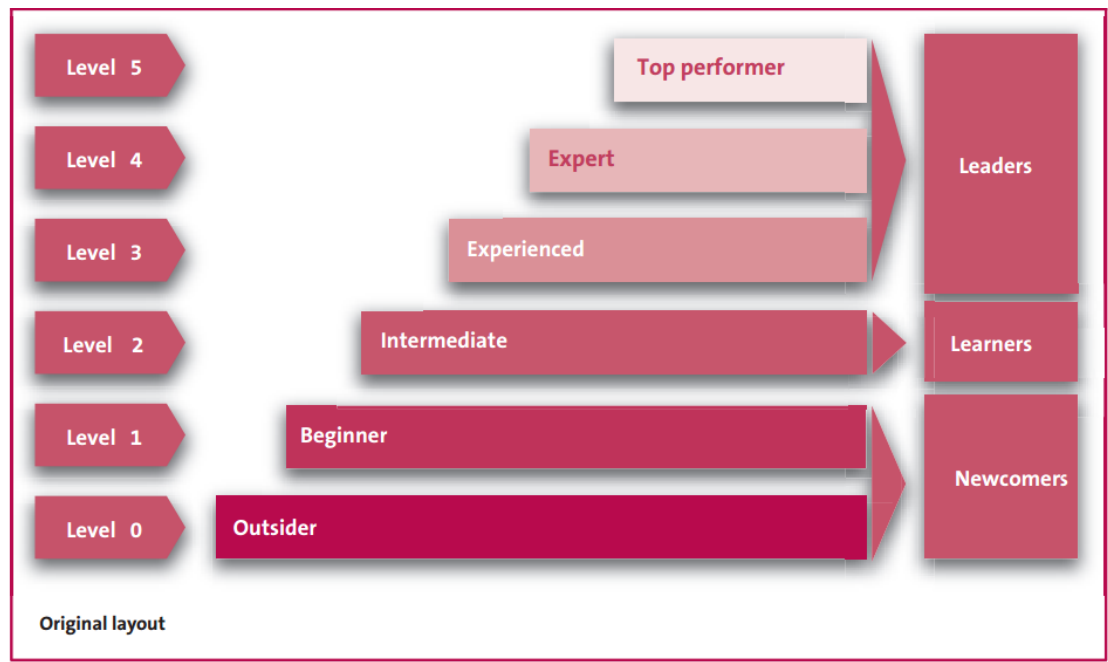

Figure 2. The six dimensions of the "Industrie 4.0 Readiness" model [7].

\section{6- Results of German Companies Maturity Evaluation}

The comparative basis of German Industry, used in this article as a reference, was given by a survey conducted in 2015 by VDMA, which applied the Industry 4.0 maturity evaluation model in 289 small, medium and large German industries. The study aimed to support German mechanical engineering companies and industries to adopt Industry 4.0, evaluating the level of readiness of these companies. The study was a partnership with IW Consult and FIR of RWTH Aachen University, which developed an on-line tool, to be used by interested companies, to evaluate their preparation for Industry 4.0 [7]. 
The general results of the readiness evaluation of German companies, in the six dimensions of the model, are presented in the graph shown in Figure 3:

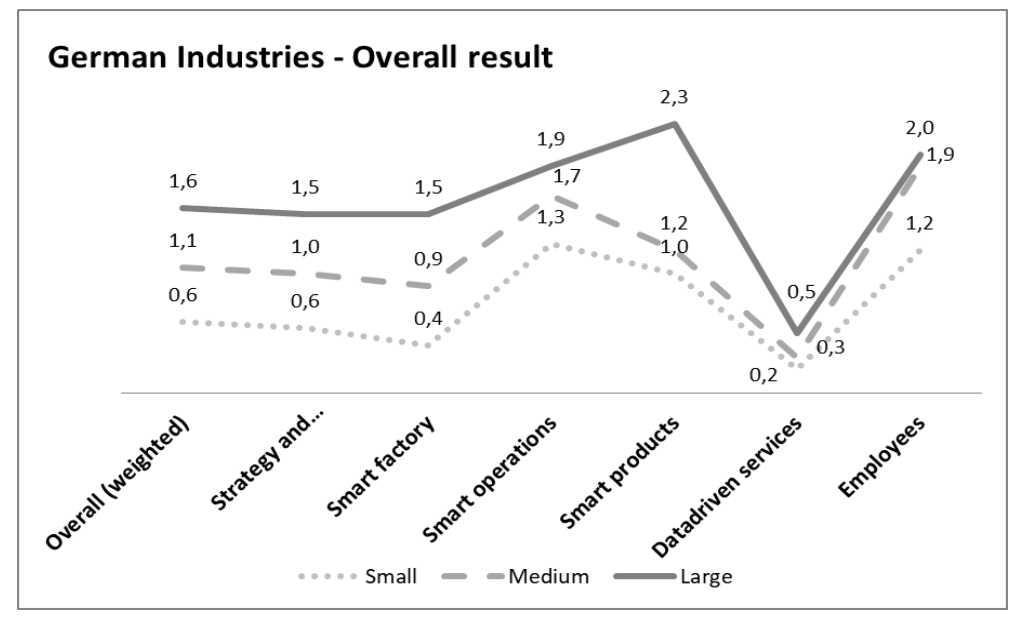

Figure 3. Overall result of Industry 4.0 maturity evaluation of German companies by size [7].

The result of the general average of the German companies evaluated in the VDMA study, on a scale of 0 to 5, was 0.9, indicating the Outsider level. The results of the survey showed that large companies stand out from small and medium sized companies in all dimensions. Only in the Data-Driven Services dimension the three groups have very close results, which is the dimension with the lowest value (0.2, 0.3 and 0.5). Also, in the Employees dimension, the results were similar for large and medium-sized companies (1.9 and 2.0).

Considering all companies, $76.5 \%$ are classified as Newcomers, that is, are at levels 0 or 1 . At level 2, called Learners, are $17.9 \%$. Finally, 5.6\% are in levels 3 to 5 and are classified as Leaders.

Regarding the expectations of German companies in relation to Industry 4.0, the study indicated that more than $60 \%$ of companies expect to increase revenues, increase their product or service portfolio and increase customer retention rates. 57.2\% said that were already involved in the Industry 4.0 issue, but, for the most part, 53\% of industry in general, has defined themselves as an "observer". Overall, these results show that Industry 4.0, for German companies, is associated with clear business opportunities and objectives [7].

\section{7- Results of Maturity Evaluation in Industry 4.0 of Brazilian Companies Studied}

The result of the general average of Brazilian companies (from Espírito Santo State) was 0.94, on a scale of 0 to 5 , classified as Newcomers. This result is similar, slightly higher, that obtained in the German companies' valuation, which was 0.9. The large companies presented superior results for five of the six dimensions and only in the dimension Employees the medium companies obtained greater value. To Data Driven Services dimension, the three groups, Large, Medium and Small companies, present very close results, been the dimension with the lowest evaluation of all, similar to German companies. The results of medium-sized companies for some dimensions are very close to the results of large companies, but for two dimensions are smaller than those of small companies, such as Smart Products and Data-Driven Services. In this latter dimension, the average companies surveyed presented "zero" as result.

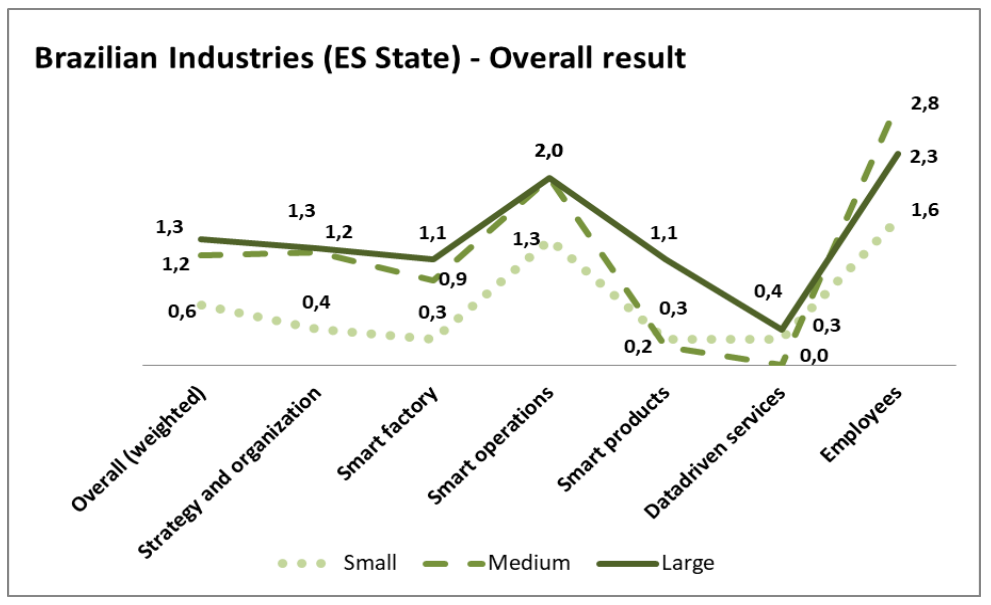

Figure 4. Overall result of Industry 4.0 maturity evaluation of Brazilian companies by companies' size. 
Regarding the groups, $77.8 \%$ are classified as Newcomers, that is, are in levels 0 to 2, and $22.2 \%$ are Learners, being in level 3. In levels 4 or 5, classified as Leaders, there are no Brazilians companies. Regarding the expectations of Brazilian companies on Industry 4.0, the study identified a lack of clear definitions. Considering all surveyed companies, $61.9 \%$ said that still do not know or are studying the subject and only one third intend to develop an Industry 4.0 project. Asked about the greatest difficulties, $71.4 \%$ indicated that it is to plan the best solution and $33.3 \%$ to define the best business model. About the term to develop the project, companies do not see as very urgent, because 42.9\% did not set a deadline and $33.3 \%$ think in the medium term, in two years. At the all, these results show that Brazilian companies studied still do not see Industry 4.0 as an opportunity for growth or results improvement, clearly being in a "wait and see" position.

\section{8- Comparative Analysis of Brazilian and German Results}

The intention of the study is not to make a direct comparison of the Brazilian and German industries to know which stands out. The comparison aims to identify important factors to guide the path to be followed by Brazilian companies, with reference to the German companies that aims the leadership in Industry 4.0. In the result of the general average, in six dimensions of VDMA model, the companies present practically the same level, 0.9 for the Germans and 0.94 for the Brazilian ones, both being defined as Outsider (value 0 to 1 of a scale until 5).

Analyzing the six dimensions in a specific way, the average results are practically identical in three dimensions: Strategy, Smart Factory and Data-Driven Services. German companies are significantly superior in Smart Products, which demonstrates the highest level of embedded technology of German products. The Brazilian companies presented slightly better results in Smart Operations and, with some surprise, superior results in the Employee dimension. The graph of Figure 5 shows this comparison of average overall results in the six dimensions of the model used.

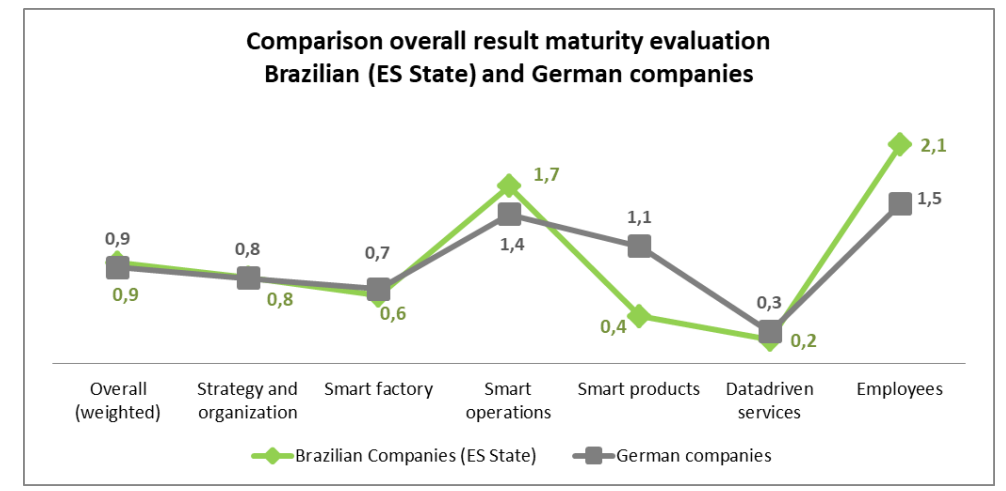

Figure 5. Overall result of Industry 4.0 maturity evaluation in the six dimensions of VDMA model, for Brazilian companies and German Industry.

Regarding group classification, in the Leaders (3 to 5), Learners (2) and Newcomers (0 to 1) levels, the comparison of the two Industries shows an interesting difference. The percentage of Brazilian companies studied is slightly higher at the Newcomers and Learners levels, because 5.6\% of German companies are at Leaders level, and there are no Brazilian companies (ES State) at this level. It's mean that German companies already invest in Industry 4.0 more intensely, especially the companies that develop industrial technology, in which the German Industry stands out.

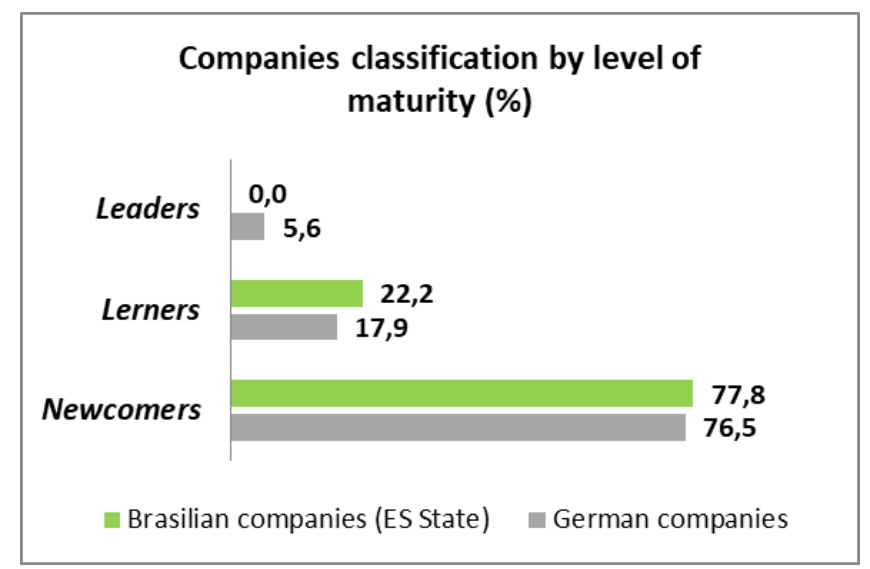

Figure 6. Comparison the classification by groups Newcomers (0 to 1), Learners (2) and Leaders (3 to 5 ). 
When comparing the overall results of Brazilian companies (ES State) with German companies classified as Leaders, Learners and Newcomers, the differences of realities are more evident. Although the general average the results are close (See Figure 5), except for the Smart Products and Employees dimensions, when compared to the German Leaders companies, that are really investing in Industry 4.0, the differences are quite significant in all dimensions. Even though this comparison is not totally correct, because are distinct populations, the intention is to show that there is already a great distance for the German companies that are leading and investing in the Industry 4.0.

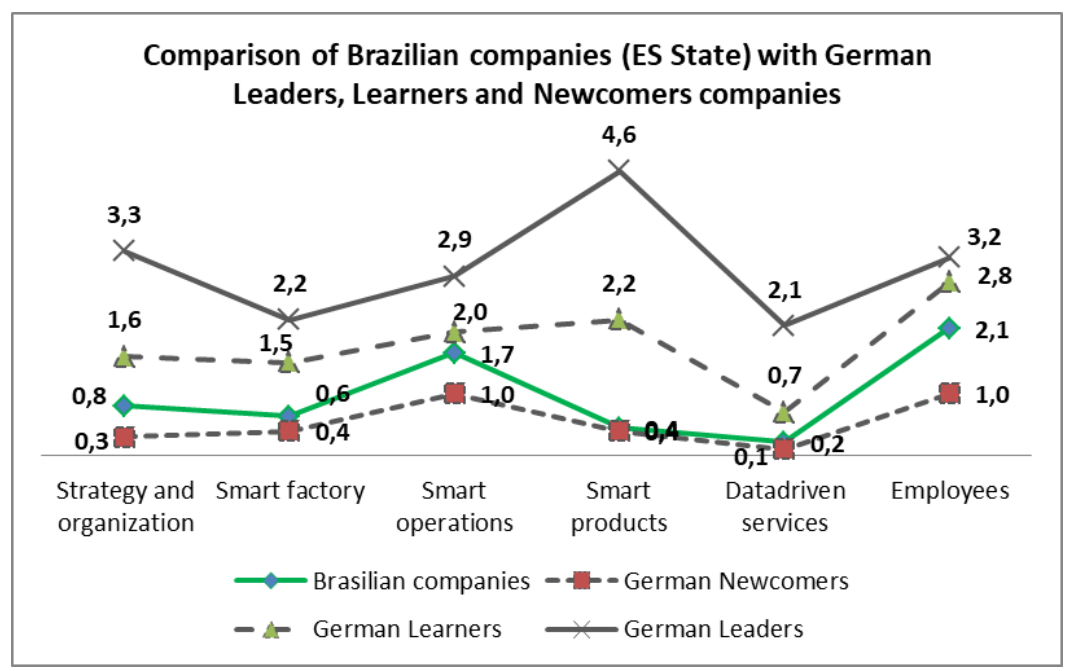

Figure 7. Comparison of overall result of Brazilian companies (ES State) with German companies classified as Newcomers (0 to 1), Learners (2) and Leaders ( 3 to 5$)$.

Another point of comparison, among Brazilian and German companies, which was possible to study, was the difficulties for adoption the Industry 4.0. Table 2 lists, in order of importance, the six main difficulties identified by each group. It's clear that the lack of definition on the part of the Brazilian companies is more significant.

Table 2. Major difficulties for adoption of Industry 4.0, by importance (Source: VDMA to German companies [7]).

\begin{tabular}{|c|c|c|}
\hline \multicolumn{3}{|c|}{ Major difficulties to adopt the Industry 4.0 } \\
\hline \multicolumn{2}{|c|}{ For Brazilian companies (ES State) } & For German companies \\
\hline 1. & Plan the best solution & 1. Lack of clarity about economic benefit \\
\hline 2. & Investment Resources & Lack of expertise or skilled labor \\
\hline 3. & Define the best business model & Lack of norms and standards \\
\hline 4. & Know where to start & General lack of clarity, hesitancy \\
\hline 5. & To know if there will be a market & Lack of confidence in data security \\
\hline 6. & Have or meet people with competence & 6. Unresolved legal issues \\
\hline
\end{tabular}

While Brazilian companies (ES State) have the greatest difficulty in planning the best solution for Industry 4.0, for German companies the greatest difficulty is the lack of clarity regarding the economic benefit. Of the six difficulties faced by Brazilian companies studied, three are related to the planning of the solution, one related to resources to invest, another if there will be a market and, for last, to find competent people.

Analyzing the difficulties presented by the German companies, the main question is related to the economic benefit and not the solution itself. After, comes the concern with the workers qualification. Technical issues, such as data security, come in follow, as well as unresolved legal issues, and are not quoted concerns about resources for investment.

\section{9- Essential Points for Adoption the Industry 4.0 by Brazilian Companies}

In addition to the comparative analysis of the results of the maturity model, expectations and difficulties, the Brazilian companies from ES State were asked what needs to be done to support the transition to Industry 4.0. The main issues presented are highlighted in the Figure 8. 


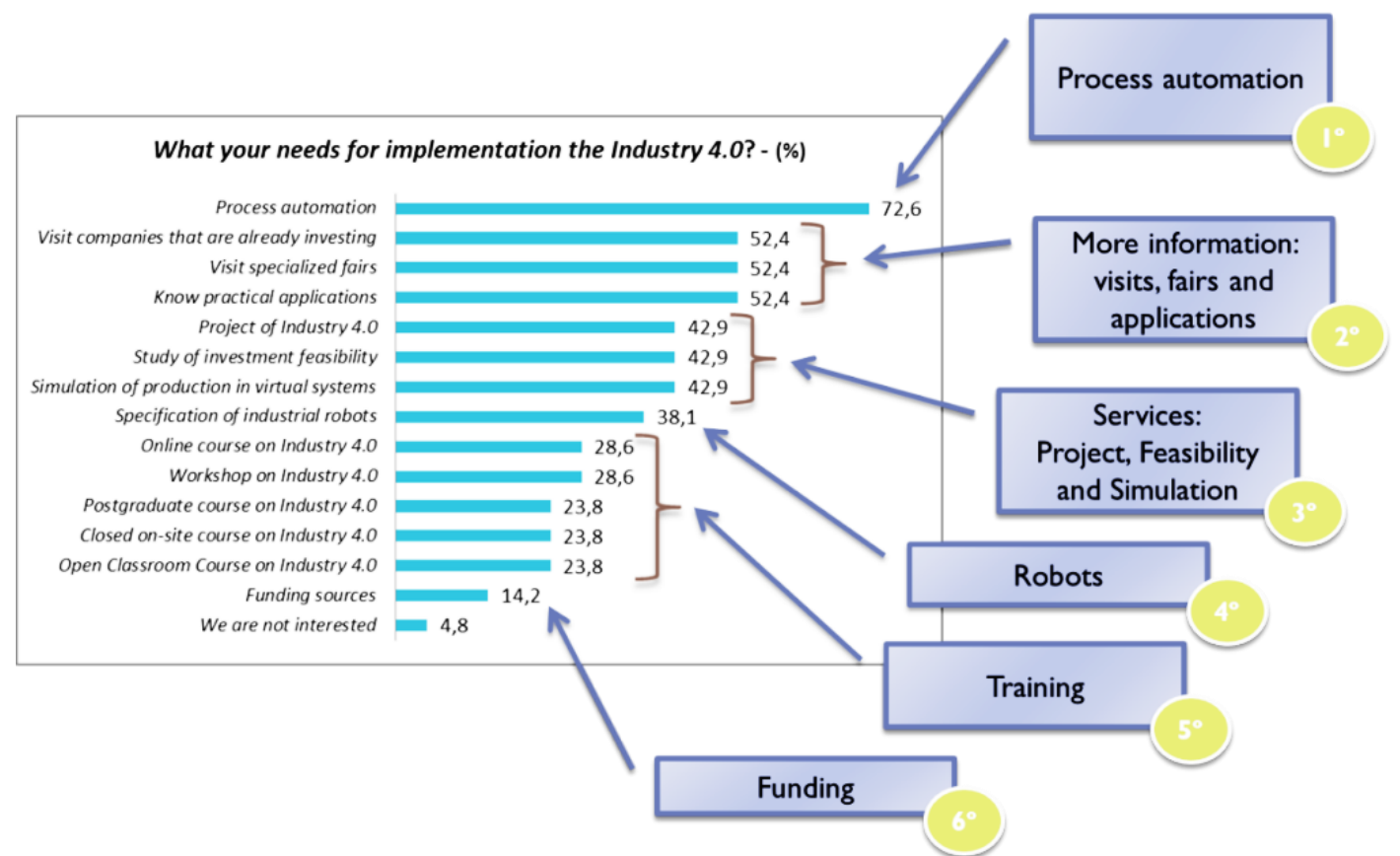

Figure 8. What needs to be done to support the transition of Brazilian companies to Industry 4.0.

The issues, presented in order of importance, were grouped for a better understanding, being:

1- Process Automation;

2- More information;

3- Support services: feasibility study, design and simulation;

4- Use of robots;

5- Training;

6- Resources for Investment.

With this list of priorities, it becomes clear that the Brazilian companies studied want, first of all, to increase the level of automation of their processes, seeking improvement in productivity, an important challenge of the Brazilian Industry. As there are uncertainties and little understanding of Industry 4.0, especially of the solutions applied, secondly arises the intention to obtain more information, knowing success stories and visiting specialized fairs. Next, comes the need for services to help companies in the projects, in the feasibility analysis and simulation for decision making. The use of robots, which appears in fourth position, aligns with the first question that is the automation of processes. Then, in fifth place, that comes the concern with qualified people. Investment resources appear last, in counterpoint to the difficulties presented in Table 2, which appears with the second major difficulty.

In summary, what was indicated as of greater importance to support Brazilian companies (ES State) in the transition to Industry 4.0 was: process automation, more information to better understand and services for project and decision support.

\section{0- Conclusions}

The comparative analysis of the maturity level in Industry 4.0 indicates that, on average, Brazilian and German companies are at the same level, with a value of 0.9 on a scale of 0 to 5 . However, $5.6 \%$ of German companies are at the "leaders" level, with a score between 3 and 5, and no Brazilian company surveyed is at this level. Some companies, especially those that develop technologies for industrial production, are already very advanced in implementing the Industry 4.0. Even in Germany, others, especially small and medium-sized companies, still adopt a "wait for see" approach [30].

The greatest expectation of Brazilian companies was in relation to process automation, to increase the productivity, being a great challenge for the Brazilian industry that occupies the 80th place in the productivity ranking, being three times less than the German one [31]. The lowest level in Smart Products presented by Brazilian companies, being 0.4 against 1.1 for German ones, indicates the need for more investments in innovation and technology, being another great challenge for the Brazilian Industry, which occupies the 64th place in the Global Index of Innovation with Germany in $3^{\text {rd }}$ place [20]. In the Employees dimension, the average results of Brazilian companies show a higher 
level than the German ones, 2.1 against 1.5, seeming meaningless, which can be a mistake in underestimating the need to prepare the workforce. Industry 4.0 will require capable professionals to use advanced technologies.

The Strategy dimension had an average score of 0.8 , on a scale of 0 to 5 , for both Brazilian and German companies, a value far below the required for the current moment of business change. This new era will require a new type of entrepreneur, more open to relationships, able to align the investment decision in Industry 4.0 with the companies' strategy and willing to keep up with the changes in the present world if he wants to continue existing and prosper.

\section{1- Acknowledgements}

We are grateful, for the support given to the research, to SENAI-ES - National Service for Industrial Learning, FINDES - Industry Federation of Espírito Santo State and the Fraunhofer Institute IPK.

\section{2- Funding}

This work received financial support from SENAI-ES - National Service for Industrial Learning, being a project of the agreement between this institution and UFES - Federal University of Espírito Santo State.

\section{3- Conflict of Interest}

The author declares that there is no conflict of interests regarding the publication of this manuscript. In addition, the ethical issues, including plagiarism, informed consent, misconduct, data fabrication and/or falsification, double publication and/or submission, and redundancies have been completely observed by the authors.

\section{4- References}

[1] Schwab, Klaus. "The Fourth Industrial Revolution”. World Economic Forum (2016). Available online: https://professionallearning.education.gov.scot/media/1352/the-fourth-industrial-revolution-what-it-means-and-how-to-respondworld-economic-forum.pdf. (accessed on 18 July 2020).

[2] Kane, Gerald C.; Palmer, Doug; Phillips; Kiron, David, and Buckley, Natasha. "Aligning the Organization for Its Digital Future". MIT Sloan Management Review and Deloitte University Press (July 2016) Available online: https://sloanreview.mit.edu/projects/aligning-for-digitalfuture/?gclid=EAIaIQobChMI087q95KE6wIViQiRCh0Qpg8CEAAYA SAAEgJFpPD_BwE (accessed on 18 March 2020).

[3] Oxford Economics. "Digital Spillover-Measuring the true impact of the digital economy" (2017) Available online: http://www.huawei.com/minisite/gci/en/digital-spillover/files/gci_digital_spillover.pdf (accessed on 21 May 2020).

[4] Bukht, Rumana and Heeks, Richard. "Defining, Conceptualising and Measuring the Digital Economy". Development Informatics Working Paper no. 68 (August 3, 2017). doi:10.2139/ssrn.3431732.

[5] BMBF - Bundesministerium für Bildung und Forschung/Federal Ministry of Education and Research. "The new High-Tech Strategy - Innovations for Germany". Berlin (2014).

[6] International Monetary Fund (IMF). World Economic Outlook Database. Available online: https://www.imf.org/external/pubs /ft/weo/2020/01/weodata/index.aspx (accessed on 25 July 2020).

[7] VDMA/IMPULS; IW. "Industrie 4.0 Readiness". Aachen (2015). Available online: https://industrie40.vdma.org/documents/4214230/26342484/Industrie_40_Readiness_Study_1529498007918.pdf/0b5fd5219ee2-2de0-f377-93bdd01ed1c8. (accessed on 11 April 2020).

[8] Vey, K.; Fandel-Meyer, T.; Zipp, J. S.; and Schneider, C. "Learning \& Development in Times of Digital Transformation: Facilitating a Culture of Change and Innovation”. International Journal of Advanced Corporate Learning (iJAC). Vol 10 , No 1. (2017): 22-32. doi:10.3991/ijac.v10i1.6334.

[9] Burke, R.; Mussomeli, A.; Laaper, S.; Hartigan, M.; and Sniderman, B. "The smart factory - Responsive, adaptive, connected manufacturing”. Deloitte University Press (2017) Available online: https://www2.deloitte.com/us/en/insights/focus/industry-40/smart-factory-connected-manufacturing.html. (accessed on 12 March 2020).

[10] Osterrieder, Philipp, Lukas Budde, and Thomas Friedli. "The Smart Factory as a Key Construct of Industry 4.0: A Systematic Literature Review.” International Journal of Production Economics 221 (March 2020): 107476. doi:10.1016/j.ijpe.2019.08.011.

[11] ACATECH - National Academy of Science and Engineering. "Recommendations for implementing the strategic initiative INDUSTRIE 4.0-Final report". Berlin (2013). Available online: https://en.acatech.de/publication/recommendations-forimplementing-the-strategic-initiative-industrie-4-0-final-report-of-the-industrie-4-0-working-group/ (accessed on 19 July 2020).

[12] Zhong, Ray Y., Xun Xu, Eberhard Klotz, and Stephen T. Newman. "Intelligent Manufacturing in the Context of Industry 4.0: A Review.” Engineering 3, no. 5 (October 2017): 616-630. doi:10.1016/j.eng.2017.05.015. 
[13] CNI - Confederação Nacional da Indústria. "Oportunidades para a indústria 4.0: aspectos da demanda e oferta no Brasil". Brasília (2017). Available online: https://www.portaldaindustria.com.br/publicacoes/2018/2/oportunidades-para-industria-40aspectos-da-demanda-e-oferta-no-brasil/ (accessed on 12 March 2020).

[14] Digital Transformation Monitor. “Germany: Industrie 4.0.” European Commission (2017). Available online: https://ec.europa.eu/growth/toolsdatabases/dem/monitor/sites/default/files/DTM_Industrie\%204.0.pdf (accessed on 28 March 2020).

[15] The World Factbook. "Country comparison: Exports". Available online: www.cia.gov/library/publications/the-worldfactbook/rankorder/2078rank.html. (accessed on 20 July 2020).

[16] Workman, D. "World's Top Export Countries". World's Top Exports (2020). Available online: http://www.worldstopexports.com/worlds-top-export-countries/. (accessed on 1 August 2020).

[17] GTAI. "Industrie 4.0 - Smart manufacturing for the future". GTAI - Berlin (2014).

[18] CNI - Confederação Nacional da Indústria. "Perfil da Indústria Brasileira". Portal da Indústria. Available online: www.portaldaindustria.com.br/estatisticas - 2020 (accessed on 27 July 2020).

[19] World Economic Forum. "The Global Competitiveness Report 2018" (2019). Available online: https://www.weforum.org/reports/how-to-end-a-decade-of-lost-productivity-growth (accessed on 18 August 2020).

[20] Cornell University, INSEAD, WIPO. “Global Innovation Index 2019” (2019). Available online: https://www.globalinnovationindex.org/gii-2019-report (accessed on 1 July 2020).

[21] Liao, Yongxin, Eduardo Rocha Loures, Fernando Deschamps, Guilherme Brezinski, and André Venâncio. "The Impact of the Fourth Industrial Revolution: a Cross-Country/region Comparison.” Production 28, no. 0 (January 15, 2018). doi:10.1590/0103-6513.20180061.

[22] Mitsumori, Yaeko. "An Analysis of the Transformation of Mega-Pharma's Business Model Toward the Emerging Market." Emerging Science Journal 4, no. 4 (August 1, 2020): 253-262. doi:10.28991/esj-2020-01228..

[23] Gartner. "What is Industrie 4.0 and what should CIOs do about it?" Gartner Newsroom. Egham, UK (May 18, 2015). Available online: https://www.gartner.com/en/newsroom/press-releases/2015-05-18-what-is-industrie-4-and-what-should-ciosdo-about-it\#: :text=Industrie \%204.0\%20refers\%20to\%20a,automation\%20that\%20has\%20gone\%20before. (accessed on 05 January 2020).

[24] Rose, J., Vladimir, L., Milon, T. and Cappuzzo, A. "Sprinting to value in Industry 4.0 - Perspectives from and Implications for U.S. Manufactures". BCG, Chicago (2016). Available online: https://www.bcg.com/pt-br/publications/2016/leanmanufacturing-technology-digital-sprinting-to-value-industry-40. (accessed on 27 July 2020).

[25] Frank, Alejandro Germán, Lucas Santos Dalenogare, and Néstor Fabián Ayala. "Industry 4.0 Technologies: Implementation Patterns in Manufacturing Companies." International Journal of Production Economics 210 (April 2019): 15-26. doi:10.1016/j.ijpe.2019.01.004.

[26] Bitkom; Fraunhofer IAO. "Industrie 4.0 - Volkswirtschaftliches Potenzial für Deutschland". Berlin, Stuttgart (2014). Available online: https://www.bitkom.org/sites/default/files/file/import/Studie-Industrie-40.pdf (accessed on 20 July 2020).

[27] McKinsey. "Industry 4.0 - How to navigate digitization of the manufacturing sector". McKinsey Digital (2016). Available online:https://www.mckinsey.com/ /media/mckinsey/business\%20functions/mckinsey\%20digital/our\%20insights/getting\%20t he\%20most\%20out\%20of\%20industry\%204\%200/mckinsey_industry_40_2016.pdf (accessed on 1 August 2020).

[28] PWC. "Industry 4.0: Building the digital enterprise". Global Industry 4.0 Survey (2016). Available online: https://www.pwc.com/gx/en/industries/industries-4.0/landing-page/industry-4.0-building-your-digital-enterprise-april2016.pdf

[29] Schumacher, Andreas; Erol, Selim; and Sihn, Wilfried. "A maturity model for assessing Industry 4.0 readiness and maturity of manufacturing enterprises”. Science Direct. Procedia CIRP 52 (2016): 161 - 166. doi:10.1016/j.procir.2016.07.040 (accessed on 20 October 2020).

[30] Wischmann, Steffen; Wangler, Leo; and Botthof, Alfons. "Industrie 4.0, Volks- und betriebswirtschaftliche Faktoren für den“. (2015) Available online: https://vdivde-it.de/system/files/pdfs/industrie-4.0-volks-und-betriebswirtschaftliche-faktoren-fuerden-standort-deutschland.pdf (accessed on 20 July 2020).

[31] The Conference Board - Total Economy Database. Available online: www.conference-board.org/economic-outlook-2018. (accessed on 1 August 2020). 